\title{
Climber prospective teacher: Relationship beliefs and mathematics teaching practice
}

\author{
Muhtarom $^{1}$, Tatag Yuli Eko Siswono², Dwi Juniati2 \\ 1 Universitas PGRI Semarang, Indonesia \\ 2 Universitas Negeri Surabaya \\ $凶$ muhtarom@upgris.ac.id
}

\section{Article Information}

Submitted March 24, 2020

Revised April 16, 2020

Accepted April 24, 2020

Keywords

Adversity Quotient; Beliefs; Climber; Prospective Teacher.

\begin{abstract}
This research explained the description of the beliefs of prospective teacher who had an adversity quotient type climber and the relationship between beliefs and mathematics teaching practices in the classroom. One student of climber prospective teacher who had taken an internship course and had good communication skill was willing to become a research subject. Semi-structured interview and observation of learning in class were used to obtain the research data. The data that had been obtained were coded, reduced, presented, triangulated to obtain credible data, and then conclusions were drawn. The results show that the climber math prospective teacher believes that mathematics is as something dynamic, namely the space of creation, human invention that develops continuously. Teaching mathematics is student-centered through problem providing or problem solving, and learning is as a construction of student's active understanding to build knowledge. A more detailed explanation of beliefs description and the relationship with the mathematics teaching practice is described in this research.
\end{abstract}

\section{INTRODUCTION}

Understanding the differences in beliefs is very important in developing and ensuring the successful implementation of school mathematics (Dossey et al, 2006). Borg (2001) states that beliefs is a mental condition that is acknowledged to be true by someone, even though others do not acknowledge the truth. Attitude that involves a number of cognitive structures is called beliefs (Leder \& Forgasz, 2002). Beliefs is an individual's knowledge of his ability to complete mathematical tasks so as to be able to organize and implement the actions needed (Muhtarom et al, 2017a; 2017b). Beliefs is the basis for driving a person in behaving and understanding owned by an individual. Presmeg (2002) explains that beliefs and perceptions can be exchanged in the context of mathematics nature. For example when students are asked what mathematics is, they answer by expressing their views on the nature of mathematics which can also be called beliefs.

The beliefs components include beliefs about nature of mathematics, beliefs about teaching of mathematics and beliefs about learning of mathematics (Beswick, 2012; Buehl \& Fives, 2009, Ernest, 1989; Muhtarom et al , 2018; Thompson, 1992). Furthermore, each component of these beliefs consists of three categories of philosophical views, namely: instrumentalist beliefs, platonist beliefs and constructivist beliefs. The three categories of philosophical views of beliefs can be seen as hierarchical formation; instrumentalist beliefs at the lowest level (involving knowledge of mathematical facts, rules and methods as separate entities), followed by platonist beliefs (involving understanding mathematics as a consistent, connected and objective structure) and constructivist beliefs (seeing mathematics as dynamically organized structures that located in a social context) (E rnest, 1989). Furthermore, 
Beswick (2005) explains that beliefs in the same row are considered theoretically consistent, and those in the same column have been considered by some researchers to be a continuum.

Beliefs have an influence on the practice of teaching mathematics, so there is a degree of consistency between beliefs and the learning practices that are implemented (Beswick, 2008; Muhtarom et al, 2019; Thompson, 1992; Tsai, 2002). It shows how important beliefs are, so the teacher plays an important role in building students' beliefs. Beliefs held by a teacher are implemented in various actions during the process of implementing mathematics teaching. However, it is possible that there is something mismatch between the context of beliefs and the context in which teaching practices are carried out. Siswono et al, (2015) state that teachers believe mathematics more as a tool, while in learning practices they believe in the view that students should see mathematics as a human activity. The inconsistency between beliefs and learning practices in the classroom can be caused by several factors, for example factors in the classroom situation, supporting facilities, students, and previous experiences. This is reinforced by Eynde et al, (2002) explaining that a person's beliefs can change because they form, change or strengthen their beliefs any time.

The fact that a person's beliefs can change and the inconsistency between beliefs and learning practices, prospective teachers when attending an internship program at school certainly cannot avoid difficulties in the practice of learning mathematics. Supardi (2013) explains the success of learning depends on how a teacher is able to overcome the existing difficulties. Intelligence in facing a difficulty includes one type of adversity quotient (Stoltz, 2000). Adversity quotient (AQ) consists of three types, namely: quitter, camper and climber. Quitter prospective teachers who reject problems and challenges give up easily. Camper prospective teachers tend not to take too much risk and are quickly satisfied with what they have achieved. Climber prospective teachers are individuals who can be relied upon to bring about change because the challenges offered make individuals develop because they dare to take risks to implement what they know and believe (Stoltz, 2000). Climber prospective teachers try to solve the challenges faced and always be optimistic that difficulties always require someone to develop.

There is no research that explains the beliefs of prospective teachers who have AQ climber and the influence of their beliefs on learning practices in the classroom. Thus, research to explore this is needed. This is one of the novelties that distinguishes it from the previous research (Bal, 2015; Beswick, 2012; Boz, 2008; Ernest, 1989; Muhtarom et al, 2017a, 2017b, 2018; Thompson, 1992). Boz (2008) shows that most of the research subjects have instrumentalist beliefs about mathematics learning. Bal (2015) states that prospective teachers can successfully solve beliefs problems in the importance of mathematics and they need to understand it. Whereas Muhtarom et al, (2017b) explain that out of 183 mathematics prospective teacher, some do not show the consistency of beliefs about mathematics, teaching, and learning mathematics. There are $2.732 \%$ of prospective teachers who have instrumentalist beliefs about mathematics, but have platonist beliefs about teaching, and learning mathematics; $7.104 \%$ of prospective teacher students who have platonist beliefs about mathematics, and teaching, but have constructivist beliefs about learning mathematics. None of the above researchers has conducted an AQ climber review of participants in their research. Through this research, it will be shown whether participants who have AQ climber try to resolve difficulties in learning in class and still hold on to their beliefs. 
Based on the description above, the question in this research is how to describe the beliefs of prospective teachers who have AQ climber and its relationship with the practice of learning mathematics. While the purpose of this research is to describe the description of the beliefs of prospective teachers who have AQ climber and the relationship between beliefs and mathematics learning practices in the classroom.

\section{METHODS}

\section{Participant}

The process of selecting research subjects began by giving the Adversity Response Profile (ARP) questionnaire to one hundred and twenty four mathematics prospective teachers at Universities in Semarang. The results of ARP questionnaire were processed and scores were obtained from each student. The results showed that there were only two or $1.61 \%$ of prospective teachers having the AQ climber category. Prospective teachers chosen already had experience of learning mathematics practices in schools that were indicated by having taken learning planning course, internship 1 course, and internship 2 course and were declared graduated for the three courses. They should have good communication skills based on the consideration of colleague lecturers. Furthermore, prospective selected participant were given an explanation of the description of research activities to be carried out and asked their willingness to become research participant. After listening to the researcher's explanations about the research activities, only one AQ climber prospective teachers with an ARP score of 166 was willing to become a research participant.

\section{Instrument}

The instruments in this research were ARP questionnaire, semi-structured interview guidelines and observation sheets of learning practices. ARP questionnaire was used to see the AQ ability of prospective teacher that was adapted from Stoltz (2000). Interview guidelines were used to measure beliefs about the nature of mathematics, and beliefs about teaching and learning mathematics while the observation sheet was used to measure the application of AQ climber prospective teacher beliefs in learning mathematics. The results of the instrument validation were in the very valid category. While the results of the ARP questionnaire test to 163 students showed that the ARP questionnaire was reliable with a value of 0.825 , so that they are proper to be used in research.

\section{Data collection}

Research data were collected through semi-structured interviews and observations of classroom learning practices. Beliefs interviews focused on obtaining data about beliefs about the nature of mathematics, and beliefs about teaching and learning mathematics, which adopted the views of Beswick (2012), Ernest (1989), and Muhtarom et al, (2019). Beliefs about the nature of mathematics is a person's mental state of mathematics as a discipline that is acknowledged as truth. While beliefs about teaching and learning mathematics is person's mental state on various types of learning approaches, the role of teachers and students in learning, activities to motivate students to learn mathematics, and how students learn mathematics. Semi-structured interviews were conducted twice, then triangulated to obtain credible data. Table 1 illustrates the examples of interview protocols used to explore the beliefs of AQ climber prospective teacher. 
Table 1. Questions of the Semi-Structured Interview Protocol

\begin{tabular}{|c|c|c|}
\hline Research focus & Research sub focus & Question \\
\hline \multirow{4}{*}{$\begin{array}{l}\text { Beliefs about } \\
\text { nature of } \\
\text { mathematics }\end{array}$} & $\begin{array}{l}\text { Definition of } \\
\text { Mathematics }\end{array}$ & Based on your beliefs, what is mathematics? \\
\hline & $\begin{array}{l}\text { Relationship between } \\
\text { mathematics and daily } \\
\text { life }\end{array}$ & $\begin{array}{l}\text { What is the relationship between } \\
\text { mathematics and daily life? Elaborate! }\end{array}$ \\
\hline & $\begin{array}{l}\text { Development of } \\
\text { mathematical } \\
\text { knowledge }\end{array}$ & $\begin{array}{l}\text { Elaborate your belief on the development of } \\
\text { mathematics science! }\end{array}$ \\
\hline & Mathematical object & $\begin{array}{l}\text { Based on your beliefs, what is the most } \\
\text { important mathematical object? }\end{array}$ \\
\hline \multirow[t]{5}{*}{$\begin{array}{l}\text { Beliefs about the } \\
\text { teaching of } \\
\text { mathematics }\end{array}$} & Teaching approach & $\begin{array}{l}\text { Elaborate your belief on the effective } \\
\text { approach implemented in teaching } \\
\text { mathematics! }\end{array}$ \\
\hline & $\begin{array}{l}\text { The role of teachers in } \\
\text { instruction }\end{array}$ & $\begin{array}{l}\text { What is the ideal role of the teacher in } \\
\text { mathematics instruction! }\end{array}$ \\
\hline & Problem solving & $\begin{array}{l}\text { Elaborate your belief on the effective type of } \\
\text { exercises/questions to be given to the } \\
\text { students! }\end{array}$ \\
\hline & & $\begin{array}{l}\text { Who should design them, and what is the } \\
\text { source? Give your reasons! }\end{array}$ \\
\hline & $\begin{array}{l}\text { Motivation on learning } \\
\text { mathematics }\end{array}$ & $\begin{array}{l}\text { What method do you apply to motivate the } \\
\text { students to learn mathematics? Elaborate! } \\
\text { What do you do when students think that } \\
\text { mathematics is not relevant to their daily } \\
\text { life? }\end{array}$ \\
\hline $\begin{array}{l}\text { Beliefs about } \\
\text { learning of } \\
\text { mathematics }\end{array}$ & Student's role & $\begin{array}{l}\text { How should students learn mathematics? } \\
\text { What should students master to learning } \\
\text { mathematics? }\end{array}$ \\
\hline
\end{tabular}

When the AQ climber prospective teacher took part in the internship program at SMP N 6 Semarang, data collection was conducted for the practice of mathematics learning. Two learning sessions with duration $3 \times 40$ minute were recorded to obtain data about learning practices in the class. AQ climber prospective teacher taught in class VIII B of SMP Negeri 6 Semarang with the material of two-variable linear equations system.

\section{Data analysis}

Videos of learning practices in the classroom were played and watched together with AQ climber prospective teacher to explore classroom learning practices. Video recordings of learning practices in class and interview videos were transcribed, then read and verified again by AQ climber prospective teacher to ensure the accuracy of the data. The data that had been verified were then coded and analyzed to illustrate the beliefs of AQ climber prospective teacher. The data analysis technique used was an interactive model consisting of three activities that occur simultaneously: data reduction, data presentation and conclusion drawing (Miles \& Huberman, 1992). Data reduction is an activity that refers to the process of selecting, focusing on simplifying abstracts and transforming raw data in the field. Data presentation is to organize data encoded through the pairing of the first data and the second data, henceforth compared so as to obtain credible data, and draw conclusions from the data that had been collected and verify conclusions about beliefs and learning practices undertaken (Miles \& Huberman, 1992). These 
three data analysis activities are not hierarchical in nature. They are intertwined networks of interacting activities starting from before, during and after the collection of research data.

\section{RESULTS AND DISCUSSION}

Climber mathematics prospective teacher viewed that mathematics was created and then improved by other experts because humans always did research on the phenomena of everyday life so as to find mathematical knowledge. This is in line with the opinions of several experts such as Amirali \& Halai (2010), Ernest (1989), Grigutsch et al, (1998), Thompson (1992), and Viholainen et al, (2014). Mathematics is a dynamic field of human creation, continues to evolve according to patterns of discovery and the results remain open to revision (Ernest, 1989), mathematics is seen as an active construction process (Grigutsch et al, 1998), mathematics is never static (Buehl \& Fives, 2009). This belief is in line with his beliefs about teaching, and learning mathematics. Climber mathematics prospective teacher believed that the student center approach was appropriate to be applied in teaching mathematics. This is in line with the opinion of Barkatsas \& Malone (2005), Ernest (1989), and Thompson (1992) stating that learning begins by giving problems to students. Teachers guide students, discuss to explore knowledge and find solutions, present and reinforce students' works (Felbrich et al, 2008; Muhtarom et al, 2019; Stipek et al, 2001).

Climber mathematics prospective teacher provided a variety of alternative student learning experiences, ensured the freedom of students to express ideas when making mathematics problems. The purpose of giving non-routine questions is to make students develop their thinking abilities more (Muhtarom et al, 2017b). The teacher acts as a facilitator who guides students, so students find mathematical concepts and formulas with their own abilities. Facilitators can also encourage reasoning, creativity and information gathering, learning occurs when there are social interactions that involve collaborative dialogue with other students and teachers (Stipek et al, 2001), cooperative-constructivist views (Barkatsas \& Malone, 2005), and learners who are the focus rather than the content (Beswick, 2005; 2012). To ensure that students are given the freedom to explore the knowledge they have, the teacher gives non-routine problems in learning mathematics and students are also given the opportunity to make questions and solve them. Climber mathematics prospective teacher gave non-routine questions to learning practices. The following is an excerpt from the learning practices of climber mathematics prospective teacher.

Participant : Each group consists of four members (distributing student
worksheets).
Given:
3kg Apples $+2 \mathrm{~kg}$ Oranges $=65,000$
2kg Apples $+3 \mathrm{~kg}$ Oranges $=60,000$
Which is more expensive, apples or oranges? Why?
How much are $1 \mathrm{~kg}$ apples and $1 \mathrm{~kg}$ oranges?
What is the price of 5kg apples and 6kg oranges?
Students : (Students discussed to complete the questions given)


Participant: Please read the instructions. Make sure that each group member knows the answer, so all group members must understand it. You can do it from anywhere that you understand.

Participant : Also notice the algebraic operation. It is easier for you to use the first completion method (Kheisa) or the second completion method (Keiza Putri). Both methods produce the same solution, namely the price of apples $=15,000$, and the price of oranges $=10,000$. For co-curricular assignments, please create your own problems and solve them by yourselves. Please collect it after the last hour of class.

When students experienced difficulties, climber mathematics prospective teacher did not immediately tell the answer but changed the form of the question so that it could be understood by students. The guidance process was done by providing scaffolding, so students can independently construct their understanding in completing mathematical tasks. The following are examples of assistance given to students.

Participant : Try to understand the problem that Rp. 65,000 is the price of $3 \mathrm{~kg}$ apples and 2 kg oranges.

Students : (other groups) do not understand everything.

Participant : Pay attention to $3 \mathrm{~kg}$ apples $+2 \mathrm{~kg}$ oranges $=65,000$, and $2 \mathrm{~kg}$ apples $+3 \mathrm{~kg}$ oranges $=60,000$. Which do you think more expensive, orange or apple?

Student : Apples

Participant : Why are apples more expensive?

Student : When buying $3 \mathrm{~kg}$ apples and $2 \mathrm{~kg} 65,000$ oranges, and $2 \mathrm{~kg}$ apples $+3 \mathrm{~kg}$ of oranges the price is less than before. Thus, in my opinion the price of apples is more expensive.

Participant : Please do it.

Students : (students opened student books and began to understand them)

Participant: Pay attention on the problem, in your opinion, which is more expensive?

Students : (some students) Apples.

Participant : What is the reason?

Student : Based on the problem, they both are $3 \mathrm{~kg}$ : apples and oranges, but the price of oranges is cheaper, Ma'am.

Participant: If apples are expensive, how much are the apples?

Students : Rp. 15,000

Participant : How do you know? And how much are the oranges?

Students : Rp. 10,000

Participant : How do you know? and give the reason.

Students : (students only used trial and error) the principal is Rp. 15,000 and Rp. 10,000, - if included in the problem the results are correct.

Students : (students from other groups) the result is that $1 \mathrm{~kg}$ apples costs Rp. 15,000

Participant : How do you know?

Students : Rp. 45,000 divided by 3, and $1 \mathrm{~kg}$ oranges are 10,000 
Climber mathematics prospective teacher believed that in learning mathematics students had to be able to construct mathematical concepts and developed them so that they could solve varied mathematical problems. This was in line with his belief that concepts were important mathematical objects, so students could develop their understanding. This can be realized when students learn by practicing varied problems so that they can solve different problems using their own ideas, as constructivist ideas (Ernest, 1989, Thompson, 1992). Grigutsch et al, (1998) state the purpose of learning is to acquire skills in reasoning and build new things, and Beswick (2012) who views learning mathematics as an autonomous exploration of one's own interests. This beliefs was proven through two groups of students who presented the results of the questions completion using two different methods but they got the same results. One group solved the problem using reasoning, and the other group solved using the elimination method. The following is an excerpt from the learning practices of climber mathematics prospective teacher .

Participant: Kheisa's group wants to present. The others, please pay attention. Kheisa's group gets extra points .

Student : (Khesia presented the results).

To find which are more expensive: apples or oranges, we must use our reasoning. We look for the apples first, $a=$ apple, and $j=$ orange.

$3 \mathrm{a}+2 \mathrm{j}=65,000$

$2 \mathrm{a}+3 \mathrm{j}=60,000$ (apparently if the number of apples goes down and the number of oranges goes up, the price goes down 5,000; this shows that the price of oranges is cheaper)

$1 \mathrm{a}+4 \mathrm{j}=55,000$ (because the difference of price is 5,000 )

$0+5 \mathrm{j}=50,000$ (because the difference of price is 5,000 )

$\mathrm{j}=50,000: 5$

$\mathrm{j}=10,000$

Then look for the price of apples. The method is almost the same but the oranges are not bought.

$4 \mathrm{a}+1 \mathrm{j}=70,000$ (the difference of price is 5,000 )

$5 \mathrm{a}+0=75,000$ (the difference of price is 5,000 )

$5 \mathrm{a}=75,000$.

$\mathrm{a}=75,000: 5=15,000$.

Thus, the price of apples is $15,000,-$ and the price of oranges is 10,000 , -

In conclusion, the price of apples is more expensive because when the number of apples goes down, the price also goes down.

Climber mathematics prospective teacher believed that mathematical knowledge developed to adapt to phenomena in everyday life, then discovered concepts, mathematical formulas, and were used to solve mathematical problems and in everyday life. It had something to do with the way the prospective teacher began learning by giving contextual and realistic problems to students so that they were really close to daily life (Muhtarom et al, 2017b). Through giving a problem, actually the prospective teacher had shown how to motivate students by giving challenging questions with difficulty level from easy to difficult (gradual), and giving an understanding that mathematics was useful in everyday life. This is in line with the opinion 
of Stipek et al, (2001) stating that the constructivist belief teacher uses motivational strategies based on substantial qualities such as loading challenges from mathematical assignments or problems. Thus, the teacher has given students the opportunity to develop solutions to mathematical problems, and allows students to play an active role in learning activities.

The climber mathematics prospective teacher provided information that the beliefs about mathematics had ever changed, which initially the climber mathematics prospective teacher believed that mathematics could become a mathematical science that could develop and be open to be revised. The influencing factors were lecturers, especially mathematics philosophy and reading books. This shows that educators have influenced students' beliefs, as Muhtarom et al, (2017b), and Muhtarom et al, (2018) provide illustrations that teachers' beliefs have influenced their students' beliefs. Muhtarom et al, (2017b) and Muhtarom et al, (2019) explain that the large number of mathematics prospective teachers have a platonist view, derived from the mathematics experience at school and the lecture program so far that had strengthened his belief. The climber mathematics prospective teacher also confirmed that the beliefs were based on the experience. This is in line with the opinion of Chapman (2008) that explains beliefs is a mental condition in which something is acknowledged true by someone, even though other people do not acknowledge the truth, something that is considered true, and it can come from experience, either real or just imagined.

\section{CONCLUSIONS}

The results of the research indicate the consistency of the beliefs of climber prospective teacher about mathematics, beliefs about teaching mathematics and learning mathematics. The beliefs of climber mathematics prospective teacher are in line with the view that mathematics is something dynamic, namely space for creation, human inventions that develop continuously, teaching mathematics is students centered through problem providing or problem solving, and learning is as a construction of active understanding of students to build knowledge. What is believed by the climber prospective teacher has become a value for him so that it is really implemented in mathematics teaching activities in the classroom. The next interesting thing that needs to be explained is how the beliefs of camper and quitter prospective teachers, as well as the impact of the beliefs on mathematics teaching practices in the classroom.

\section{AUTHOR CONTRIBUTIONS STATEMENT}

$\mathrm{M}$ as the conceptor in this study. TYES and DJ worked as design of research articles.

\section{REFERENCES}

Amirali, M., \& Halai, A. (2010). Teachers' knowledge about the nature of mathematics: A survey of secondary school teachers in karachi, Pakistan. Bulletin of Education and Research, 32(2), 45-61.

Bal, A. P. (2015). Examination of the mathematical problem-solving beliefs and success levels of primary school teacher candidates through the variables of mathematical success and gender. Educational Sciences: Theory and Practice, 15(5), 1373-1390.

Barkatsas, A. T., \& Malone, J. (2005). A typology of mathematics teachers' beliefs about teaching and learning mathematics and instructional practices. Mathematics Education 
Research Journal, 17(2), 69-90.

Beswick, K. (2005). The beliefs/practice connection in broadly defined contexts. Mathematics Education Research Journal, 17(2), 39-68.

Beswick, K. (2008). Influencing teachers' beliefs about teaching mathematics for numeracy to students with mathematics learning difficulties. Mathematics Teacher Education and Development, 9, 3-20.

Beswick, K. (2012). Teachers' beliefs about school mathematics and mathematicians' mathematics and their relationship to practice. Educational Studies in Mathematics, 79(1), $127-147$.

Borg, M. (2001). Teachers' belief. [online]. ELT Journal, 55(2).

Boz, N. (2008). Turkish pre-service mathematics teachers' beliefs about nature of mathematics teaching. Australian Journal of Teacher Education, 33(5), 66-80.

Buehl, M. M., \& Fives, H. (2009). Exploring teachers' beliefs about teaching knowledge: Where does it come from? does it change? The Journal of Experimental Education, 77(4), 367-408.

Chapman, O. (2008). Self-study in mathematics teacher education. In Symposium on the Occasion of the $100^{\text {th }}$ Anniversary of ICMI, Rome (Italy).

Dossey, J. A., McCrone, S. S., \& O’Sullivan, C. (2006). Problem solving in the PISA and TIMSS 2003 assessments. Technical Report NCES 2007-049. Washington DC: US Department of Education.

Ernest, P. (1989). The impact of beliefs on the teaching of mathematics. Science and Technology Education, 35, 99-101.

Eynde, P., Corte, E.D., \& Verschaffel, L. (2002). Framing students' mathematics-related belief. a quest for conseptual clarity and a comprehensive categorization. In Gilah, L. C., Erkki, P., \& Gunter, T. (Ed). Belief: A hidden variable in mathematics education?. Dordrecht: Kluwer Academic Publishers.

Felbrich, A., Müller, C., \& Blömeke, S. (2008). Epistemological beliefs concerning the nature of mathematics among teacher educators and teacher education students in mathematics. ZDM Mathematics Education, 40(5), 763-776.

Grigutsch, S., Raatz, U., \& Törner, G. (1998). Einstellungen gegenüber mathematik bei mathematiklehrern. Journal Für Mathematik-Didaktik, 19(1), 3-45.

Leder, G. C., \& Forgasz, H. J. (2002). Measuring mathematical belief and their impact on the learning of mathematics: A new approach. . In Gilah, L. C., Erkki, P., \& Gunter, T. (Ed). Beliefs: A hidden variable in mathematics education? Dordrecht: Kluwer Academic Publisher.

Miles, M., \& Huberman, A. M. (1992). Analisis data kualitatif: Buku sumber tantang metodemetode baru. Jakarta: UI Press.

Muhtarom, M., Happy, N., Nursyahidah, F., \& Casanova, A. (2019). Pre-service teacher's beliefs and knowledge about mathematics. Al-Jabar: Jurnal Pendidikan Matematika, 
10(1), 101-110.

Muhtarom, M., Juniati, D., \& Siswono, T. Y. E. (2017a). Exploring beliefs in a problem-solving process of prospective teachers with high mathematical ability. Global Journal of Engineering Education, 19(2), 130-136.

Muhtarom, M., Juniati, D., \& Siswono, T. Y. E. (2017b). Consistency and inconsistency of prospective teachers' beliefs in mathematics, teaching, learning and problem solving. AIP Conference Proceedings (Vol. 1868, p. 050014). College Park: AIP Publishing.

Muhtarom, M., Juniati, D., \& Siswono, T. Y. E. (2018). Exploring prospective teachers' beliefs about nature of mathematics. Journal of Engineering and Applied Sciences, 13(10), 35473554.

Muhtarom, M., Juniati, D., Siswono, T. Y. E., \& Rahmatika, I. (2018). Teachers' and students' beliefs in mathematics at state senior high school 5 Semarang. Jurnal Riset Pendidikan Matematika, 5(1), 64-72.

Muhtarom, M., Juniati, D., \& Siswono, T. Y .E. (2019). Examining prospective teacher beliefs and pedagogical content knowledge towards teaching practice in mathematics class: A case study. Journal on Mathematics Education, 10(2), 185-202.

Presmeg, N. (2002). Beliefs about the nature of mathematics in the bridging of everyday and school mathematics practices. In Gilah, L. C., Erkki, P., \& Gunter, T. (Ed). Beliefs: A Hidden Variable in Mathematics Education? Dordrecht: Kluwer Academic Publisher.

Siswono, T. Y. E., Rosyidi, A. H., Kurniasari, I., \& Astuti, Y. P. (2015). Exploring elementary teachers' belief and understanding about mathematical problem solving. Paper International Conference on Mathematics, Natural Sciences, and Education (ICoMaNSEd).

Stipek, D. J., Givvin, K. B., Salmon, J. M., \& MacGyvers, V. L. (2001). Teachers' beliefs and practices related to mathematics instruction. Teaching and Teacher Education, 17(2), 213-226.

Stoltz, P. G. (2000). Adversity Quotient: Turning obstacles into opportunities (mengubah hambatan menjadi peluang). Terjemahan oleh: T. Hermaya. Jakarta: PT. Gramedia Widiasarana Indonesia.

Supardi, U. S. (2013). Pengaruh adversity quotient terhadap prestasi belajar matematika. Jurnal Formatif, 3(1), 61-71.

Tsai, C. C. (2002). Nested epistemologies: Science teachers' beliefs of teaching, learning and science. International Journal of Science Education., 24(8), 771-783.

Thompson, A. G. (1992). Teachers' beliefs and conceptions: A synthesis of the research. in d. a. grouws (ed.), Handbook of research on mathematics teaching and learning (pp. 127146). Reston: National Council of Teachers of Mathematics.

Viholainen, A., Asikainen, M., \& Hirvonen, P. E. (2014). Mathematics prospective teachers' epistemological beliefs about the nature of mathematics and the goals of mathematics teaching and learning in the beginning of their studies. Eurasia Journal of Mathematics, Science \& Technology Education, 10(2), 159-171. 